\title{
Notes on the Distribution of Burrowing Isopoda and Amphipoda in Various Soils on the Sea Bottom near Plymouth.
}

\author{
G. I. Crawford, M.A.,
}

Assistant-Keeper at the British Museum (Natural History) : late Student Probationer at the Plymouth Laboratory.

With 1 Figure in the Text.

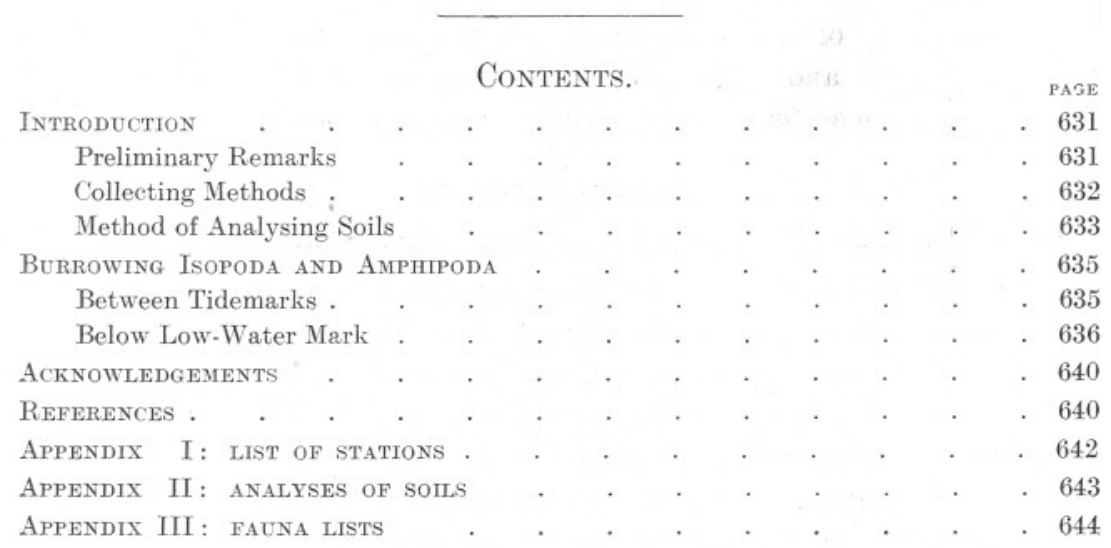

INTRODUCTION.

Preliminary Remarks.

THE earliest detailed account of the nature of the sea bottom near Plymouth is that of Allen (1899), wherein analyses of the soils on the $30 \mathrm{fm}$. line are coupled with lists of the animals collected by trawl and dredge. Ford (1923) described a number of soils in shallower water, and gave a quantitative list of the bottom fauna, collected with a grab which covered an area of $0 \cdot 1 \mathrm{sq} . \mathrm{m}$. Smith (1932) described in great detail the soils of the area of shell-gravel which surrounds the Eddystone Lighthouse. By none of these workers, however, was special attention paid to the smaller burrowing Crustacea, which are often overlooked unless they are made the special object of collecting. Some species, e.g. of Bathyporeia and Ampelisca, may be very common, and certainly play an important part in the ecology of the sea-bottom. See Steven (1930) and Hunt (1925).

The object of the present paper is to summarize the results of my 
collecting of Isopoda and Amphipoda in 1934 and 1935, and to record the nature of the soil in which each species was found. From their small size and the habit of many species of burrowing by ejecting sand grains in a swimming current it seems to me probable that the burrowing Amphipoda, Isopoda, and Cumacea are much influenced in their distribution by the nature of soil. I did not, unfortunately, make precise observations on the Cumacea, or on the Tanaidacea, collected.

Reibisch (1905 and 1906) recorded 87 species of Amphipoda dredged in the North Sea. Many of these were burrowing species, and he recorded the type of bottom from which a number of species were obtained. Zirwas (1911) treated the Isopoda similarly. The distribution of Isopoda and Amphipoda between tidemarks is discussed in a number of papers, among which that of Elmhirst (1931) is outstanding.

The methods of burrowing of Haustorius arenarius are described by Dennell (1933), and those of Talitrus saltator, Bathyporeia robertsoni, Microprotopus maculatus, and Corophium volutator by Schellenberg (1929).

\section{Collecting Methods.}

The collections in Cawsand Bay were made from M.B. Gammarus, chiefly with the fine-meshed dredge (Naturalist's pattern) and the D-net. The contents of the dredge (usually about 10 litres) were emptied into a bucket and repeatedly stirred up, the fauna being skimmed off with a flat hand-net of bolting silk, until no more appeared. The contents of the D-net were similarly treated, after the finer particles of sand had been washed out through the mesh. One collection was made with a tow-net towed clear of the bottom behind the shrimp-trawl frame: a sort of ground-rope of loose chain was so fixed as to stir up the fauna of the bottom. As a collecting instrument this was as effective as the D-net, but less convenient to use.

\section{The othere collections Treere made from the S.S. Solpho with the fine-} meshed dredge (Salpa-pattem). Sometimes a canvas bag was fastened inside the net to avoid washing out of particles of soil of the finer grades: but since the soil was observed to pack very firm in the dredge, and to be washed out very slowly even in rough weather, I think it probable that samples taken from the centre of the mass brought up were in their original condition, and that the loss of soil was not considerable, even when the canvas bag was not used.

The soil brought up was emptied into baths of measured capacity, and an estimate made of its volume. A sample was set aside in a breffit for analysis in the laboratory, and the remainder was sieved through the four "Challenger" sieves. The soil which pollected with a hand-net. stirred in water and the smallest specim were probably complete except In fine weather the resulting collections were probably 
for very small specimens, or rare species : in rough weather small species must have been frequently missed.

The number of specimens of any species obtained in this way is not a measure of the density of population. The area over which the dredge was worked is not known nor the depth to which it dug, and, owing to the shape of the digging edge, the surface layers of the bottom were collected over a larger area than the deepest layers sampled. It is possible, but I think unlikely, that some species of Amphipoda and Isopoda, as of worms, lie too deep for the dredge to secure them.

For quantitative work a grab would have been necessary, and would have to have been used for repeated observations on the same station over a long period, since the density of animals on the sea-floor is subject to large seasonal and annual fluctuations (Blegvad, 1928). It was not possible to take such an extended set of observations, and considering the further disadvantages of the grab enumerated below, I decided that the finemeshed dredge was the most suitable instrument for a preliminary survey of the distribution of Amphipoda and Isopoda on various soils. The grab is only effective in calm weather and is not equally effective on all grounds ; for comparing the numbers of animals on diverse grounds it is probably inferior to the dredge. The soils at Plymouth are less suited to the grab than the rather uniform muddy soils chiefly worked by Blegvad (1928) and other Danish workers. Moreover, the instrument available at Plymouth covers only $0 \cdot 1$ sq. m., whereas a 50-litre dredge haul covers 1 sq. m., assuming the mean depth of the digging edge to be $5 \mathrm{~cm}$.

\section{Method of Analysing Soils.}

At least 400 c.c. of soil from each station (in stony grounds up to 1000 c.c.) were graded in the sieves standardized by Allen (1899), following precisely the procedure detailed by him on pp. 378-380. By this method eight grades are distinguished.

I. Stones. All inorganic material which will not pass through a $15 \mathrm{~mm}$. sieve.

II. Coarse Gravel. Material left on a $5 \mathrm{~mm}$. sieve.

III. Medium Gravel. Material left on a $2.5 \mathrm{~mm}$. sieve.

IV. Fine Gravel. Material left on a $1.5 \mathrm{~mm}$. sieve.

V. Coarse Sand. Material left on a $1.0 \mathrm{~mm}$. sieve.

VI. Medium Sand. Material left on a $0.5 \mathrm{~mm}$. sieve.

VII. Fine Sand. Material which passes through a $0.5 \mathrm{~mm}$. sieve and, when stirred up with sea-water, settles in 1 minute.

VIII. Silt. Remains in suspension at the end of 1 minute.

The dry-weight of soil of each grade is expressed as a percentage of the total dry-weight of the sample, and these 8 percentages form a record of 
the nature of the soil, which is comparable with all records similarly obtained. This analysis, particularly for very silty soils, is not so precise as analysis by elutriation methods. It distinguishes, however, between soils which cannot easily be distinguished by inspection.

It should be noted that in soils containing high percentages of fine sand (VII) the mean size of the particles of this grade is much larger in clean grounds (i.e. those with little silt) than in silty grounds. It would, therefore, be misleading to express the nature of such soils by " numerical representations" such as Smith (1932) was able to apply to the Eddystone gravels. Further, in grades I to VI, and perhaps also in grade VII, some of the particles are thin laminae of shell and slate, and others are rounded pebbles. The pebbles in any grade are heavier than the laminar particles, and a pebbly gravel is less suited for small burrowing Crustacea than a shelly gravel, the larger particles of which afford good shelter to Gammarids

Theoretically the eight percentages expressing the nature of the soil are free to assume any values which add up to 100 . In practice I found that only certain types of values were assumed, and it is likely that everywhere on the sea-bottom the currents will restrict the freedom of these percentages to assume any value. For example, it is improbable that the percentages of grades I and III will be high, and those of II and IV low. The soils examined by Allen (1899) and by myself can be simply classified as below.

I have arbitrarily defined a simple soil as one having a maximum in one grade, and either no secondary maximum or one of less than $5 \%$ : and a mixed soil as one having a secondary (rarely also a tertiary) maximum of over $5 \%$ of the whole. A mixed soil may be regarded as formed by the mixture of two (or three) simple soils in proportions only roughly ascertainable from the percentages of the 8 grades. Unless the coarser of these components is present in much greater bulk, the lighter gives character to the soil. For example, a mixture of fine sand and coarse gravel will support a certain number of species usually found in fine sand alone, but not those from coarse gravel alcne. The fine sand between the particles of gravel maintains its own character, but by filling in the interstices entirely alters that of the gravel. Most of the mixed soils which I have examined consist of a medium or fine sand with a small mixture of coarse or medium gravel.

The simple soils may be arbitrarily classified as follows :

"mud"-maximum in VIII.

"fine sand with mud"-maximum in VII : VIII $>10 \%$.

"fine sand"-maximum in VII : VIII from 2 to $10 \%$.

"fine clean sand"-maximum in VII : VIII $<2 \%$.

"medium sand " up to "stone"-maximum in VI up to I. 
I have found no soil with a maximum in I, and such a ground would probably be barren. The coarser the soil, the less well defined the maximum.

By this classification the Rame mud grounds are included under " fine sand with mud," but they have a much higher percentage of silt than the soils analysed from Cawsand Bay, and the mean size of fine sand particles is smaller. It is in comparing soils with high percentages of silt that the method adopted here is least satisfactory.

A list of stations and of soil-analyses is given in Appendices I and II. The localities best worked were Cawsand Bay, Whitsand Bay and Bigbury Bay.

\section{Burrowing Isopoda AND Amphipoda.}

A list of hauls and of catches of Isopoda and Amphipoda is given in Appendix III (p. 644), with separate lists of burrowing and non-burrowing species. Intertidal collections are not included in these lists but are summarized below.

\section{Between Tidemarks.}

Only 11 species of burrowing Isopods and Amphipods were collected from intertidal areas, and in only a few localities (marked with an asterisk) were precise measurements taken of the size of soil particles. In other places an estimate was made of the type of soil.

\section{Isopoda.}

Eurydice pulchra Leach. Drake's Island*, Mothecombe*, Treyarnon (N. Cornwall), Saunton (N. Devon); in fine to coarse sand from about half-tide mark downwards.

\section{AMPHIPODA.}

Ampelisca brevicornis (A. Costa). Drake's Island in muddy sand ; Salstone in very muddy sand, both at L.W.M.

Bathyporeia pelagica Bate. Trevarrian (N. Cornwall)*, Kynance Cove, Mothecombe*, Wembury*, fine to medium sand, from half-tide mark downwards.

Haustorius arenarius (Slabber). Mothecombe, sand, L.W.M.

Urothoë brevicornis Bate. Drake's Island, sand, L.W.M.

$U$. grimaldii var. poseidonis Reibisch. Salcombe Millbay, fine clean sand*, L.W.M.

Perioculodes longimanus (Bate and Westw.). St. Michael's Mount, Salcombe Millbay, muddy to fine sand, L.W.M.

Pontocrates arenarius (Bate). Wembury*, Dawlish, fine to medium sand from half-tide mark downwards.

P. norvegicus Boeck. Trevarrian (N. Cornwall), Kynance Cove, Mothecombe*, Wembury*, fine to medium sand from half-tide mark downwards.

Guernea coalita (Norman). Drake's Island, shell gravel at L.W.M.

Photis longicaudata (Bate and Westw.). Salstone, muddy soil, at L.W.M.

With the exception of Eurydice pulchra and Urothoë grimaldii var. poseidonis (both of which have been caught below tidemarks by other 
collectors) these species are all contained in the list of burrowing species collected below low-water mark, and considered in the next section.

\section{Below Low-Water Mark.}

The three areas on which my information is most complete are Cawsand Bay, Whitsand Bay, and Bigbury Bay. The soil in Cawsand Bay (St. 2) is fine sand with mud. That in Whitsand Bay (St. 34-39) and Bigbury Bay (St. 43-47, 53, 54) is fine clean sand. I also collected in Bigbury Bay from gravel (St. 50, 51), and fine sand with mud (St. 52), see Fig. 1.

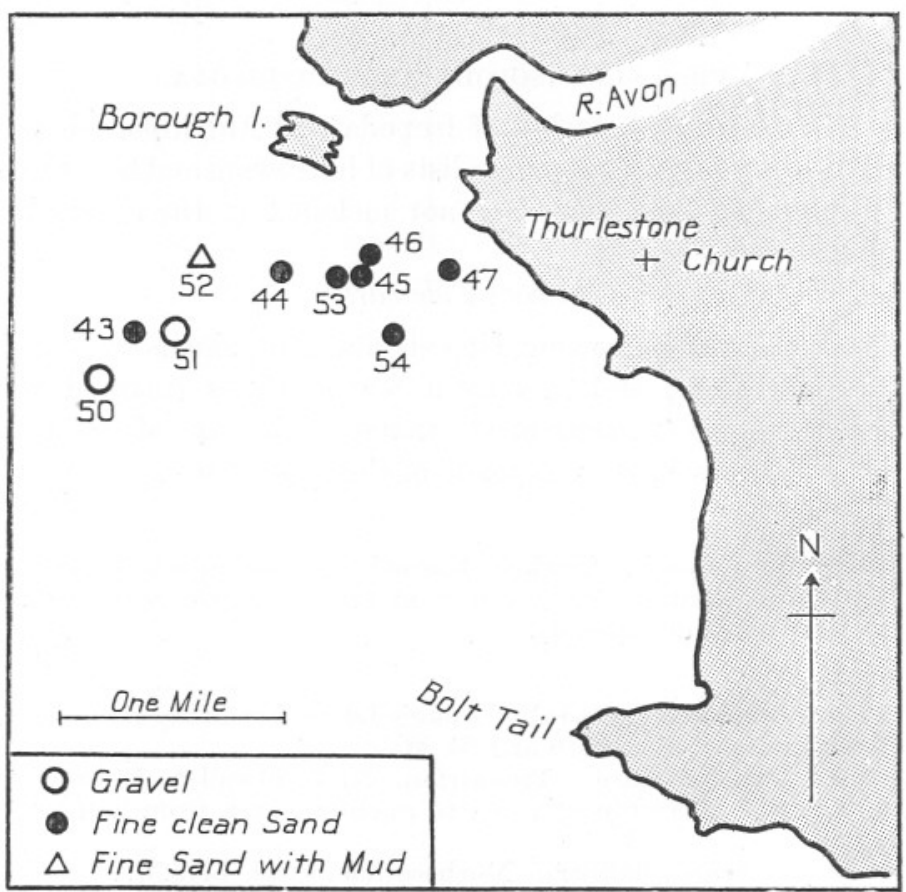

FIG. 1.-Map showing positions of stations in Bigbury Bay, and nature of soil.

A dredge haul from the latter contained Amphiura filiformis and Syndosmya alba, abundant; Echinocardium cordatum, 20 specimens about $1 \frac{1}{2}$ inches long; Cardium echinatum, 6 large specimens; and a quantity of fragments of oak and hawthorn leaves. The precise numbers of specimens of Isopods and Amphipods caught at these and other stations are noted in Appendix III (p. 644); the following lists simply classify the burrowing species as "abundant," meaning more than 100 in at least one of the hauls, and " few," meaning not more than 10 in any haul. Intermediate frequencies are denoted by "common." 


\section{AMPHIPODA.}

\section{Cawsand Bay (Fine Sand with Mud).}

Ampelisca brevicornis, common.

Bathyporeia pelagica, ${ }^{*}$ few.

Urothoë elegans, few.

Argissa stebbingi, 2 in 7 hauls.

Harpinia antennaria, common.

Perioculodes longimanus, common.

Synchelidium haplocheles, few.
Monoculodes carinatus, 1 in 7 hauls. Megaluropus agilis, few.

Guernea coalita, 1 in 7 hauls.

Microprotopus maculatus, common. Siphonoecetes colletti, 1 in 7 hauls. Corophium crassicorne, common.

The burrowing faunas of the fine clean sand in Whitsand Bay and Bigbury Bay afford an interesting comparison. The soil is very similar, except that that of Bigbury is reddish, while that of Whitsand is greyish-white and composed largely of shell and slate. Some of the hauls in Whitsand contained loose weed, with a fauna of its own, but the presence of weed did not appear to affect the burrowing fau na.

\section{IsOPODA.}

Eurydice spinigera,

\section{AMPHIPODA.}

Hippomedon denticulatus,

Ampelisca brevicornis,

Bathyporeia guilliamsoniana,

B. pelagica,

Haustorius arenarius,

Urothoë brevicornis,

Leucothoë sp. indet,

Perioculodes longimanus,

Pontocrates arenarius,

$P$. norvegicus,

Synchelidium sp. indet.,

Megaluropus agilis,

Siphonoecetes dellavallei,

Corophium crassicorne,
Whitsand Bay. Bigbury Bay.

(Fine clean sand)

few. $\quad 2$ in 7 hauls.

2 in 6 hauls. $\quad 4$ in 7 hauls.

- $\quad 3$ in 7 hauls.

few. few.

common. abundant.

1 in 6 hauls.

few.

-

few.

- few.

- few.

- few.

- $\quad 1$ in 7 hauls.

The remaining stations are too scattered to form the basis of similar comparisons.

A systematic consideration follows of all burrowing species of Isopoda and Amphipoda collected below low-water mark.

\section{Isopoda.}

Eurydice spinigera was present in small numbers in Bigbury Bay and Whitsand Bay in fine clean sand. Two specimens of E. truncata were obtained from coarse sand near the Eddystone.

I only found E. pulchra between tidemarks. It swam freely in pools on the sands, and in the sea as the tide rose. From this fact, and from the frequency with which species of Eurydice are captured in tow-nets, it

\footnotetext{
* See p. 639
} 
appears that they are not so intimately dependent on the soil as are the burrowing Amphipoda. E. pulchra burrows with great ease, principally by means of a swimming current.

\section{Amphipoda.}

Hippomedon denticulatus was never common. It was present in fine clean sand in Whitsand Bay and Bigbury Bay : also in Bigbury at St. 51 in coarse stony gravel (with a little fine sand) : and in Eddystone coarse sand.

Ampelisca spp. were very common except in fine clean sand. None were found in Whitsand Bay and only a few A. brevicornis in Bigbury Bay. A. brevicornis was common in Cawsand Bay, and intertidally at Drake's Island, in fine sand with mud; and in much muddier soil on the Salstone just above low-water mark. It was not found in coarse grounds. The remaining four species were all frequent in mixed soils. A. spinipes and A. typica were moreover found in gravels, the former more commonly. A. tenuicornis was found in mixed soils, and in the very muddy fine sand of the Rame mud, often in large numbers. A. diadema was present less commonly in mixed soils.

The burrowing of Ampelisca is not dependent on a flow of water set up by the pleopods, but is performed by the scraping and hauling of the gnathopods, aided by the urosome as soon as it gets a purchase. The fifth and sixth pereiopods are spread out and prevent sand rolling into the hole. In captivity $A$. tenuicornis made a case of sand-grains (not pebbles) loosely aggregated, and indistinguishable from the substratum.

The local Haustoriidae burrow almost entirely by ejecting sand-grains in a powerful swimming current. They do not form tubes. They are preeminently inhabitants of sand, and soils containing much clogging silt or many heavy particles are not suitable for them. It is noticeable that the coarseness of the soils inhabited by species of the genus Urothoë is in proportion to the size of adult specimens.

The burrowing of Haustorius is described by Dennell (1933). That of Urothoë brevicornis and U. grimaldii var. poseidonis appeared to me very similar. Burrowing movements were made with the antennae and gnathopods; the third and fourth pereiopods swept off encroaching particles to one side ; while the fifth to seventh pereiopods formed a funnel, widest at the hind end, along which the pleopods swept sand-grains in a powerful and diverging current. In their native soil these species burrowed out of sight within five seconds. Bathyporeia pelagica from Bigbury Bay could disappear within one second; and some Bathyporeia (sp. indet.) observed in sandy pools near Saunton, N. Devon, entered the sand without any apparent check to their rate of swimming.

Haustorius arenarius was found in fine clean sand in Whitsand Bay, 
but not in Bigbury Bay. In one unlocalized haul from Whitsand Bay four specimens were obtained. Bathyporeia pelagica was abundant and B. guilliamsoniana was present in fine clean sand in both Whitsand Bay and Bigbury Bay. Bathyporeia elegans Sars is a name applied to a slender form of $B$. pelagica with less well-developed eyes. The specimens of this genus from the finer sand of Cawsand Bay were of this form, but it is doubtful if it is a distinct species.

Of the species of Urothoë obtained the smallest is $U$. elegans, which was found in Cawsand Bay and in silty mixed soils on the Rame-Eddystone Grounds and Melampus, Plymouth Sound. U. marina, the largest species, was collected in coarse sand and fine gravel-see also Smith (1932). The two species of intermediate size, U. grimaldii var. poseidonis and $U$. brevicornis, were both found in fine clean sand, but only very locally, the former at Millbay, Salcombe (intertidally), and the latter on Drake's Island and in Whitsand Bay.

Argissa stebbingi was found in one haul from Cawsand Bay, and in D-net hauls from Middle Sound and Melampus, in rather silty soil (not analysed).

Metaphoxus fultoni was characteristic of gravels, and was even found in the stony gravel of Bigbury Bay (St. 50, where over 95\% of Grade I by weight was non-calcareous). The animal is so small that I presume it lives interstitially in the manner described by Nicholls (1935) for certain copepods. Harpinia antennaria was only found in grounds that were wholly or predominantly fine sand with mud, and was most common in Cawsand Bay.

A number of specimens of Leucothoë were found in hauls in which all the other species were certainly burrowers. It seems, therefore, that some members of this genus burrow, while others (e.g. L. spinicarpa) habitually live among sponges, ascidians, etc. The specimens from Rame mud were $L$. lilljeborgi, the rest could not be named.

The Oedicerosidae do not build tubes, and live principally in sand. They are, however, less restricted in their choice of soils than the Haustoriidae, at least near Plymouth. Pontocrates arenarius and $P$. norvegicus were both found in fine clean sand in shallow water or between tidemarks, but never together. Perioculodes longimanus was characteristic of the finer Cawsand Bay soil, and was present in Bigbury but not in Whitsand Bay. Synchelidium haplocheles was found in Cawsand Bay, and Synchelidium sp. (perhaps maculatum) was present in small numbers in Bigbury Bay. Westwoodilla caecula was infrequent in mixed soils. Appendix III contains only one record of Monoculodes carinatus, and that is from Cawsand Bay; but it appears (Ford, 1923) that gravel is its usual substratum. A specimen that I dredged from shell-gravel on New Grounds was observed, with its scorched brownish colouring, to harmonize 
closely with that ground. Eusirus longipes was only collected from Rame mud.

Of the Gammaridae, Megaluropus agilis was common in Cawsand Bay and Bigbury Bay, and is probably a genuine burrower. Maera othonis was observed in the laboratory to make a refuge under large shell fragments by pushing out the finer soil with its second gnathopods, creeping on its side, like a Gammarus, when disturbed, and concealing itself under the first suitable fragment found. Since Cheirocratus sundevalli and Ceradocus semiserratus were found on the same gravelly or mixed grounds, I suppose that their habits are similar.

Guernea coalita is another very small species living in coarse grounds, probably interstitially.

The Photidae and Corophiidae are tube-builders, and a number are burrowers. Of the Photidae only two species were found in numbers, Microprotopus maculatus and Photis longicaudata, from mixed and simple soils with much fine sand and silt. Of the Corophiidae, Siphonoecetes dellavalle $i$ was a member of the characteristic fauna of Bigbury Bay, and Corophium crassicorne of Cawsand Bay. S. dellavallei was also dredged commonly off the bar of the River Yealm in a soil noted as "shellyslaty fine-gravel," and in small numbers inside Drake's Island. C. crassicorne was also obtained off the bar of the Yealm and at White Patches (Zostera bed), and Melampus, Plymouth Sound.

\section{Acknowledgments.}

The success of my collecting trips is practically entirely due to the help and advice of Captain Lord of the S.S. Salpa, and to the co-operation of all the crew (especially Mr. J. Martin who did much of the sieving with me). I wish to express my warmest thanks and appreciation to them all.

My best thanks are due to Dr. K. Stephensen, of the Copenhagen University Museum, who gave me his opinion on all those specimens about which I was in doubt.

\section{REFERENCES.}

Allen, E. J. 1899. On the Fauna and Bottom-Deposits near the Thirty Fathom Line from the Eddystone Grounds to Start Point. Journ. Mar. Biol. Assoc., N.S., Vol. V, pp. 365-542.

Blegvad, H. 1928. Quantitative Investigations of Bottom Invertebrates in the Limfjord, 1910 to 1927, with special Reference to the Plaice-food. Rep. Dan. Biol. Sta., Copenhagen, Vol. XXXIV (3), pp. 35-52. 
Dennell, R. 1933. The Habits and Feeding Mechanism of the Amphipod Haustorius arenarius Slabber. Journ. Linn. Soc. Zool. London, Vol. XXXVIII, pp. 363-388.

Elmhirst, R. 1931. Studies in Scottish Marine Fauna-Crustacea of sandy and muddy areas of the Tidal Zone. Proc. Roy. Soc. Edin., 1930-1, pp. 169-175.

Ford, E. 1923. Animal Communities of the Level Sea-bottom in the Waters adjacent to Plymouth. Journ. Mar. Biol. Assoc., N.S., Vol. XIII, No. 1, pp. 164-224.

Hunt, O. D. 1925. The Food of the Bottom Fauna of the Plymouth Fishing Grounds. Journ. Mar. Biol. Assoc., N.S., Vol. XIII, No. 3, pp. 560-599.

Nicholls, A. G. 1935. Copepods from the Interstitial Fauna of a Sandy Beach. Journ. Mar. Biol. Assoc., N.S., Vol. XX, No. 2, pp. 379-406.

ReIBISCH, J. 1905, 1906. Faunistisch-biologische Untersuchungen über Amphipoden der Nordsee. Wiss. Meeresunters., Kiel, Abt. Kiel, Vol. VIII, pp. 147-188 and Vol. IX, pp. 185-237.

Schellenberg, A. 1929. Körperbau und Grabweise einiger Amphipoden. Zool. Anz. Leipzig, Vol. LXXXV, pp. 186-190.

Sмiтн, J. E. 1932. The Shell Gravel Deposits and the Infauna of the Eddystone Grounds. Journ. Mar. Biol. Assoc., N.S., Vol. XVIII, No. 1, pp. 243-278.

Steven, G. A. 1930. Bottom Fauna and the Food of Fishes. Journ. Mar. Biol. Assoc., N.S., Vol. XVI, No. 3, pp. 677-706.

Zirwas, C. 1911. Die Isopoden der Nordsee. Wiss. Meeresunters., Kiel, Abt. Kiel, N.F., Bd. XII, pp. 73-118. 


\section{APPENDIX I: LIST OF STATIONS.}

No. of

Station.

6.vii.34 Cawsand Bay

(repeated

later)

$6 \quad$ 18.vii.34

Off Penlee Point .

14.viii.34

Rame mud

14.viii.34 Rame mud

14.viii.34 Rame-Eddystone

4.ix.34

4.ix.34

4.ix.34

3.x. 34

$3 . \mathrm{x} .34$

16.xi.34

,

,

4.xii. 34

22.i.35

,

,

10.v. 35

,"

Eddystone .

Eddystone .

Eddystone.

Rame-Eddystone

Rame-Eddystone

Whitsand Bay .

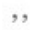

,

,

Plymouth Sound

Bigbury Bay

,"

,

,

,

,

,

\section{Marks or Bearings.}

Breakwater light on Bovisand fort : clock tower on highest near bushy-topped tree ( $2 a$ was a sample taken nearby $2 b$ was taken off Pier Cellars).

Mewstone on Wembury Church: white house (sea level) on Penlee on 3 tall trees to W. of large wood on Maker Heights. Mewstone open from Yealm Head, on trees on skyline: Penlee Point overlapping Blackball: Rame Chapel on flagstaff.

Mewstone on head to W. of Yealm : Penlee Point just overlapping Blackball: Rame Chapel on flagstaff.; About 300 yd. S.S.E. from last ; "Turritella ground."

In a direct line from Rame Head to Eddystone.

Eddystone bearing S.E. about $\frac{1}{4}$ mile.

Eddystone bearing S.E. by S. about $\frac{1}{4}$ mile.

Eddystone bearing S.S.E. about $\frac{1}{4}$ mile.

Rame Chapel on flagstaff.

Rame Chapel on flagstaff.

N.N.E. of Queener Rocks : church just in view at end of haul (going W.).

Opposite wreck of Chancellor : Rame Church inside Polhawn house.

$\frac{1}{4}$ mile W. from 35 .

E. of Shadows Rocks.

Just E. of 34 .

About 50 yd. N.E. to N. of Melampus buoy: buoy started on Picklecombe Pt., ended on middle of Drake's Is.

Burgh Is., N.E. : Bolt Tail, S.E.

Burgh Is., N.: Thurlestone Church, just S. of E.

Burgh Is., N. by W.1 W.: Thurlestone Church, E.

Burgh Is., N.W. by N.1. N. : Thurlestone Church, E. by $\frac{1}{2}$ S.

Burgh Is., N.W.: Thurlestone Church, E.

Burgh Is., N.E. : Bolt Tail, S.E. $\frac{1}{2}$ E.

Burgh Is., N.E. $\frac{1}{2}$ N. : Bolt Tail, S.E. $\frac{1}{4} \mathrm{~S}$.

Burgh Is., N.E. : Bolt Tail, S.E. by S.

Burgh Is., N. by W. : Thurlestone Church, E.

Burgh Is., N.N.W.: Thurlestone Church, E. by N.
Nature of Soil.

Fine sand with mud.

Mixed.

Fine sand with much mud.

$20-25$

As last, but less silty and grittier.

28

Mixed soil, chiefly medium sand.

ca. 30 Red fine gravel

$c a .30$ Pale sandy gravel.

ca. 30

Pale medium gravel.

Mixed soil, chiefly fine sand.

Fine sand, rather muddy and gravelly.

$3-5$

Fine clean sand.

,, ,, (weedy).

,

, , ,

,, , , (weedy).

Mixed soil (fine sand and coarse gravel).

Fine clean sand.

,, , , (rather red).

, , , (red)

, , ,

Medium stony gravel.

Coarse stony gravel.

Fine sand with mud (leares of oak, etc.) (= Ford, 1923 Station 13)

$9 \frac{1}{2} \quad$ Fine clean sand. 
APPENDIX II : ANALYSES OF SOILS.

Stations in same order as in Appendix III ; the maxima are shown in heavy type.

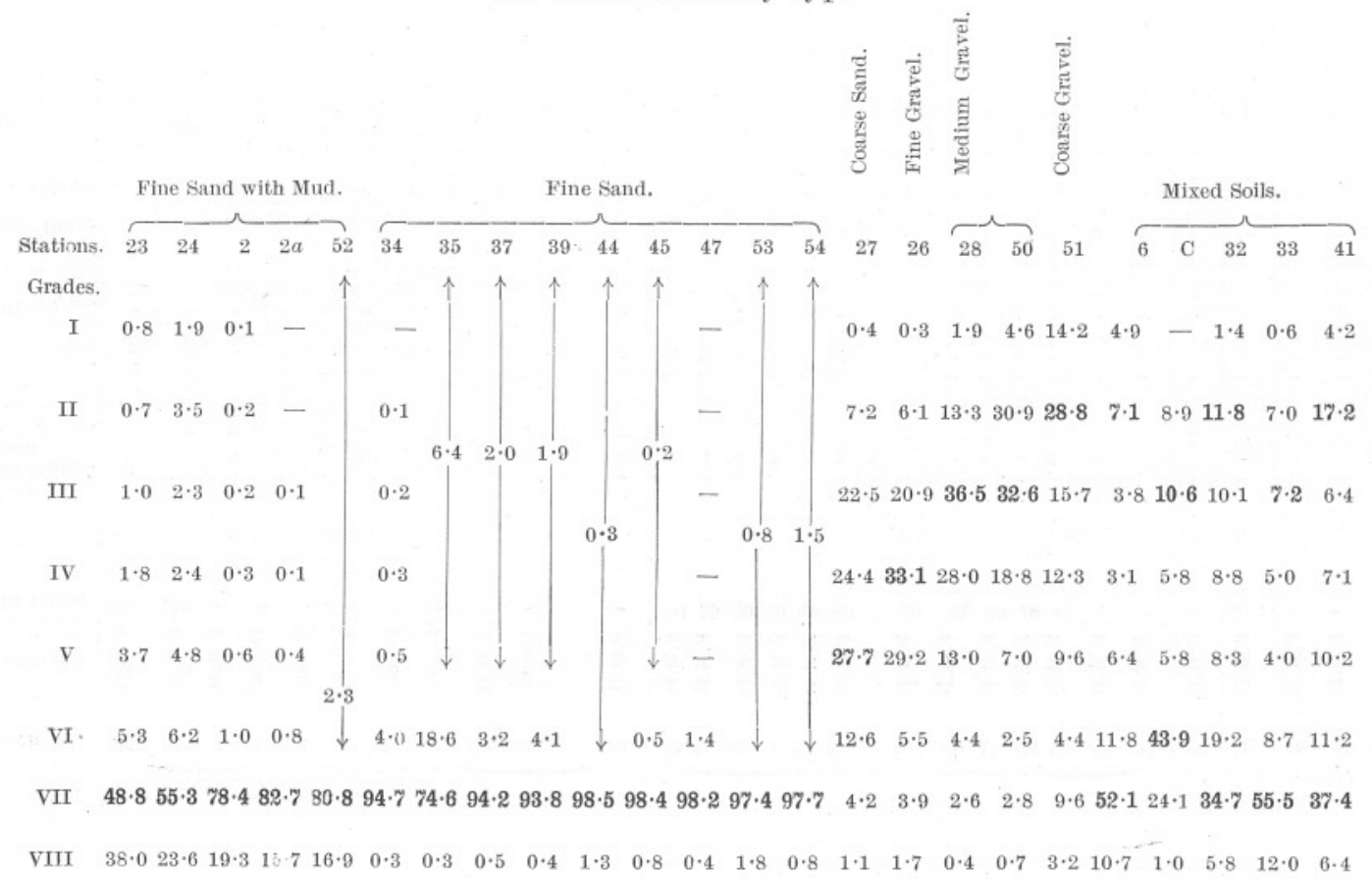


APPENDIX III : FAUNA LISTS.

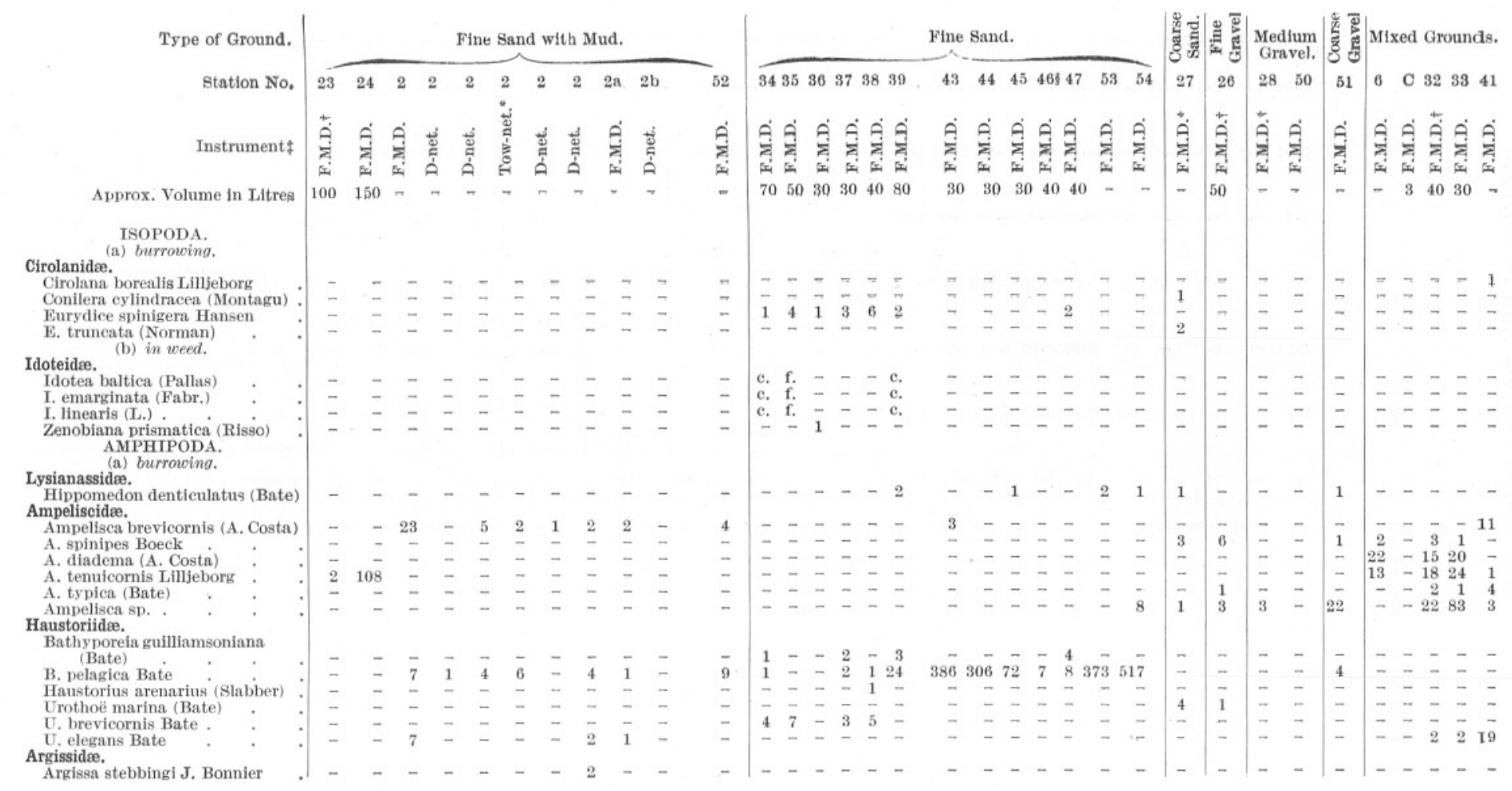


Phoxocephalidæ.

Harpinia autennaria Meinert. Harpinia sp.
Leucothoidæ.

Leucothoe lilljeborgi Boeck

Leucothoë sp.

Perioculodes longimanus (Bate \& Westwood)

Pontocrates arenarius (Bate)

.

ynchelidium sp.

Yonoculodes earinatus (Bate)

Westwoodilla caecula (Bate)

Eusiridæ.

Eusirus longipes Boeck

Cheirocratus sundevalli (Rathke) Cheirocratus sp.

Megaluropus agilis Hoek

Ceradocus semiserratus (Bate)

Maera othonis (M.-Edwards)

colita (Norman)

Microprotopus maculatus

Photis longicaudata (Bate and

Westwood) (Bnte and

Leptocheirus nims

Podoceropsis sophiæ Boeck

Megamphopus sp.

Corophiidæ.

Siphonoecetes colletti Boeck

Corophium crassicorne Brivelius

(b) in weed.

Lepidepecreum longicorne (Bate

carnes erythrophthalmus

rchomenella nana (Kröyer)

Leucothoidæ.
Leucothoë spinicarpa (Abilgaard)
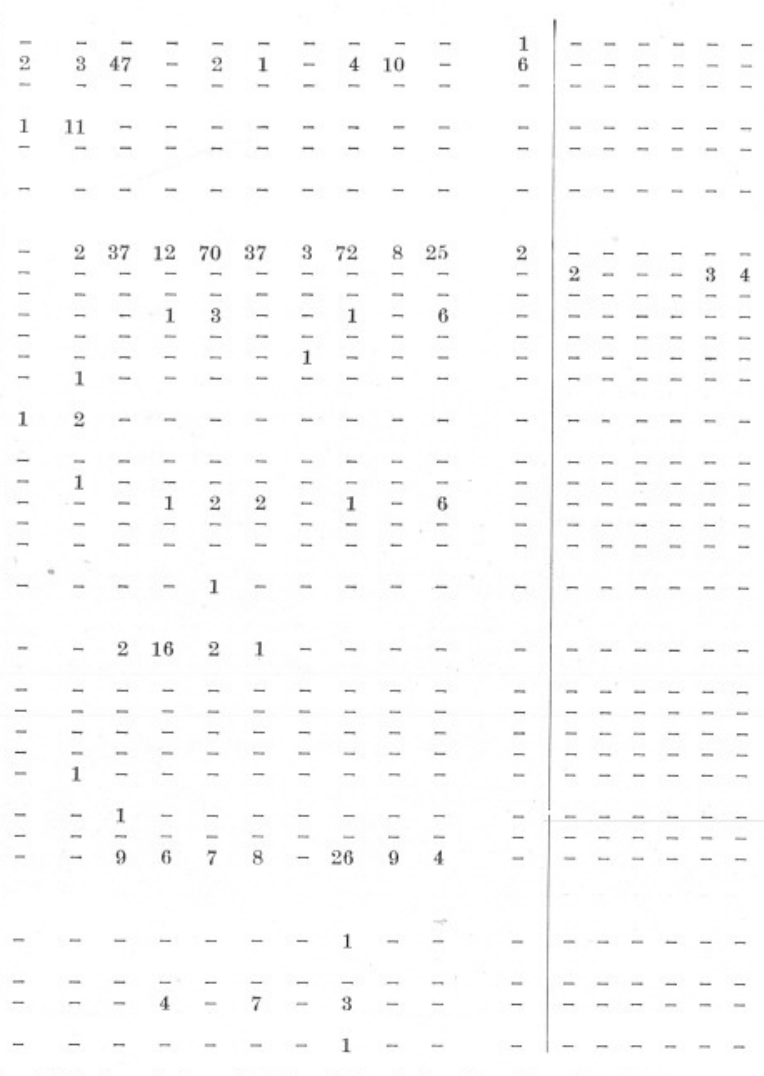

* Tow-net dragged about $1 \mathrm{ft}$. from bottom behind a chain designed to dig up the bottom.

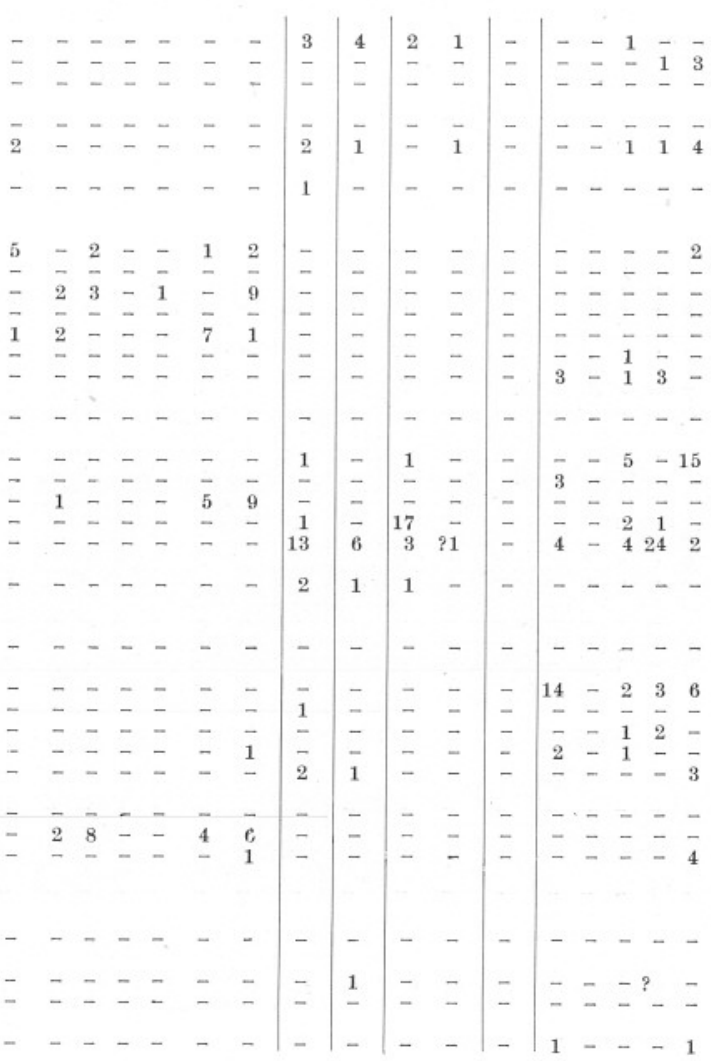

$\mathrm{c}=$ common. Many specimens lost by tube cracking. 
APPENDIX III: FAUNA LISTS-contd.

Stenothoidæe. tenothoe monoculoides (Montagu)

S. marina (Bate)

Parametopa kervillei Chevreu Acanthonotozomidæ,

Panoploea minut

Calliopiidæe.

Apherusa bispinosa (Bate).

A. Ovalipes Norman and scot Notot.

otropis swammerdami (H Milne-Edwards)

. falcatus (Metzger)

Nototropis s

Gammaridæ.

Melita palmata (Montagu)

Maera grossimana (Montagu)
Mand obsata Montagu

Gammarus locusta $(\mathrm{L})$

Gammarus sp.

Dexaminidæ.

Dexamine spinosa (Montagu)

Aora typica Kröyer

Coremapus versiculatus Norman

Photidæ.

Eurystheus maculatus (Johnston ) Amphithoë vaillanti Lucas

Amphithoe sp.

Jassider.
Jassa falcata (Montagu)

Jassa fal

Corophiidæ.

Erichthonius brasiliensis (Dana)

Corophium sextoni Crawford

c. Bollidelli G. O. Sars

Phthisica

Pariambus typicus (Krör

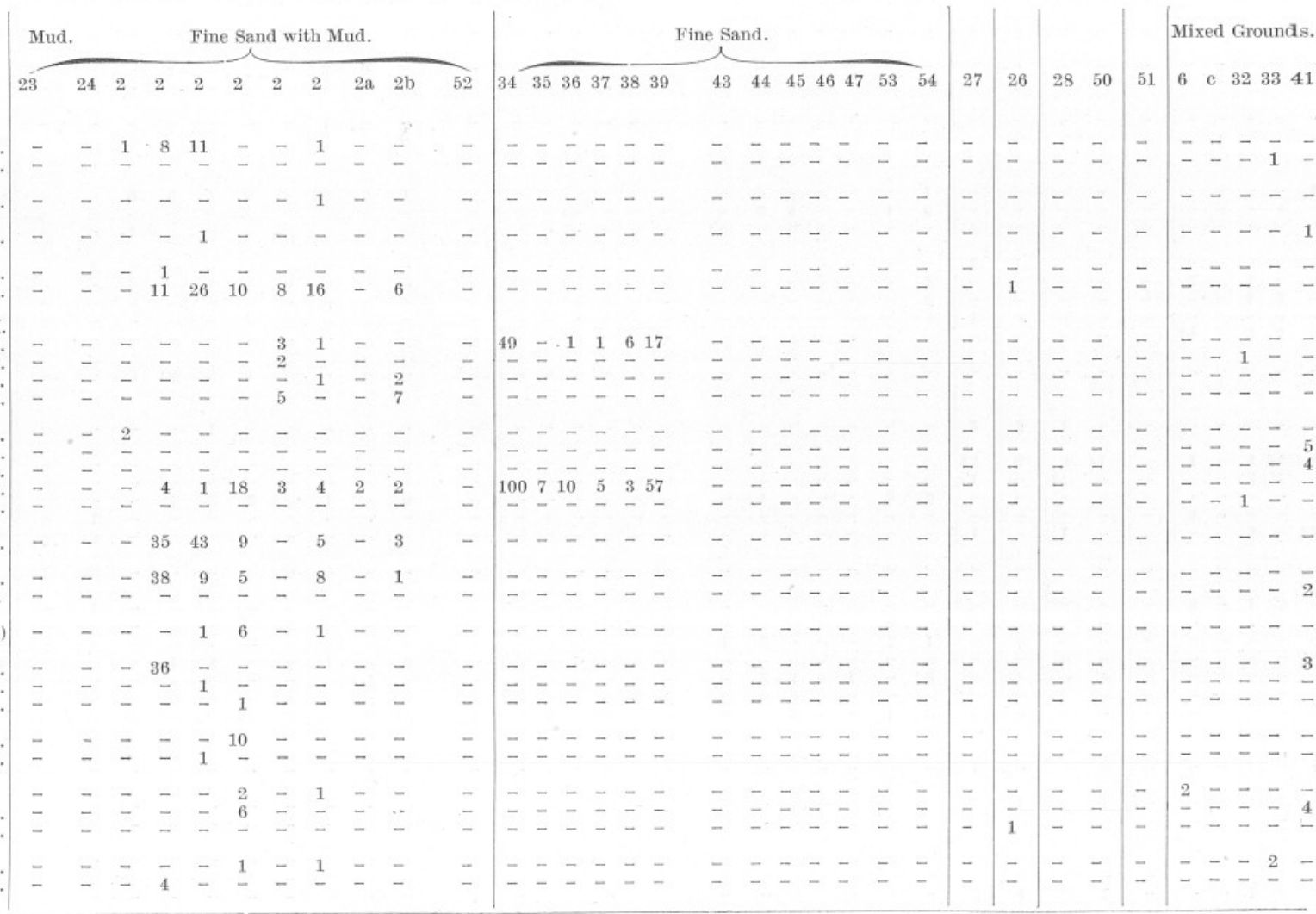

